\title{
Subject Bibliography Versus Subject Catalog and Periodical Index
}

\author{
Mr. Rogers is librarian, The Grosvenor \\ Library.
}

$\mathrm{T}^{\mathrm{T}}$ IS not too generally recognized that sub1 ject bibliography is useful to a research worker approximately in inverse proportion to his ability. Inexperienced librarians and research students least informed about subject bibliography need it most, but they turn to more obvious bibliographical tools such as the subject card catalog and general periodical indexes. Therefore, I have undertaken to demonstrate, to a certain extent statistically, what good subject bibliography can do which the card catalog and periodical indexes fail to do. This paper is based on an analysis of book and periodical citations in approximately 26 bibliographies from four recognized sources: Encyclopaedia of the Social Sciences, Dictionary of American Biography, Literary History of the United States (cited as Spiller), ${ }^{2}$ and Ebisch and Schücking, $A$ Shakespeare Bibliography. ${ }^{3}$

\section{Methodology}

Each book was checked in the Library of Congress printed catalog and in the catalog of the Grosvenor Library to determine the adequacy of the subject headings used in the card catalog. Those books which could

1 Paper presented at meeting of Bibliography Committee, A.C.R.L., Chicago, Jan. 26, 1950.

2 Edited by Robert E. Spiller [and others]. New York, Macmillan, I 948

${ }_{3}$ Ebisch, Walter, Schücking, Levin L., Oxford, The Clarendon Press, I93 I. (Editor's Note: See art cle by Wesley Simonton in this issue of College and Research Libraries, which also considers this bibliography.) not be located in either of the two catalogs were eliminated from the statistical results. All books were divided into three categories: $\mathrm{A}, \mathrm{B}$, and $\mathrm{C}$, examples and definitions of which are given in the following sections.

\section{Category A}

Category A includes those books which could be found through the subject catalog as easily as through subject bibliography because the subject headings used were reasonably related to the subject under consideration. Hardly anyone would disagree that a person working on Shakespeare would look under such obviously related subjects as ENGLISH LITERATURE, ENGLISH DRAMA, etc. However, there is one reservation with respect to Category $A$ : The card catalog lacks critical notes frequently contained in subject bibliography. For example, Spiller refers to a biography of Charles Brockden Brown by William Dunlap in these words: "The work is in fact extremely inaccurate but it has usually been followed by later writers." The Dictionary of American Biography article on Andrew Johnson, written by St. George L. Sioussat, refers to the literature on the reconstruction period in American History in these words: Hugh McCullough, Men and Measures of $a$ Half a Century (I888) was one of the first important works, by a contemporary of real significance, to give a favorable estimate of Johnson's presidency, which up to that time had been described for the most part by enemies. W. A. Dunning, Essays on the Civil 
War and Reconstruction (1898) as the first examination of the reconstruction policies with the detached view of historical scholarship exerted a determining influence on later writers. Influenced by Dunning is C. E. Chadsey, The Struggle between President Johnson and Congress over Reconstruction (1896). C. H. McCarthy, Lincoln's Plan of Reconstruction (I90I); J. W. Fertig, Secession and Reconstruction of Tennessee (1898); and J. R. Neal, Disunion and Restoration in Tennessee ( 1899 ), belong to the same period of writing.

\section{Category B}

Category $\mathrm{B}$ includes those books which might be found by a highly skilled and persistent research worker through the subject catalog, but there is considerable question if an inexperienced research worker could thus locate the books. For example the Encyclopaedia of the Social Sciences cites Edward Westermarck's The History of Human Marriage in its bibliography under "Prostitution." I think the inexperienced research worker-and I mean inexperienced bibliographically speaking-could be excused for not looking in a book on marriage for information on prostitution. Unfortunately the subject catalog will not help him in this connection.

As a second example of this category, the Dictionary of American Biography states that there are two good descriptions of Joseph Dennie. Dennie was a minor American literary figure who lived at the end of the eighteenth and in the early nineteenth centuries. He was born and reared in Boston and was graduated from Harvard. $\mathrm{He}$ spent the most productive part of his life in New Hampshire and Philadelphia as an editor, literary agent and newspaper writer. The Dictionary of American Biography states that one of the two good descriptions of Dennie is in Washington Irving's Salmagundi, No. 8. Irving patterned Launcelot Langstaff after Dennie, but of course the card catalog does not provide information of this type.
It seems to me that three things are true about Category B :

I. The highly skilled, intuitive, persistent research worker might find books of the type cited.

2. The books could be found much more quickly through subject bibliography.

3. As literature grows in all subject fields it will be necessary to rely less and less on the sheer tenacity of the scholar to wade through the literature of his immediate as well as collateral fields and to rely more and more on good subject bibliography to discipline such literature.

\section{Category C}

Category $\mathrm{C}$ includes those books which could not have been found through the subject catalog because of the absence of an adequate or related subject approach. In the section "Sources, Literary Influences and Cultural Relations," $A$ Shakespeare Bibliography ${ }^{4}$ cites an edition of Montaigne's $E_{\text {ssays }}{ }^{5}$ with an introduction by George Saintsbury which discusses the influence of Montaigne on Elizabethan drama and Shakespeare. Despite the importance of the author of the introduction, the card catalog gives no subject approach to the essay. Ebisch and Schücking (p. 67) cite a similar example, of an edition of Seneca with an introduction by T. S. Eliot. ${ }^{6}$ This introduction likewise discusses the influence of Seneca on Elizabethan drama, but there is no subject approach to the essay in the card catalog. There is a third, somewhat different example in a book entitled Biographic Clinics by George M. Gould. One section of this six-volume work discusses the effect of Lafcadio Hearn's physical maladies and poor eyesight on his work. There is no approach to this information in the card catalog, either under HEARN, AMERICAN LITERATURE or any generally related subject.

4 Ebisch and Schücking, p. 73.

- The Essays, done into English by John Florio. London, D. Nutt, 1892 .

"Seneca, His Tenne Tragedies. London, Constable \& Co., 1927. 2 ' vols. 


\section{Methodology with Respect to Periodicals}

Three categories, A, B, and C were also assigned to periodical articles. However, the periodical articles cited in the various bibliographies analyzed were not checked against the card catalog but against general periodical indexes. Two criteria were established to assist in the allocations:

I. Was the article in a magazine indexed by a general periodical index?

2. If so, did the general periodical index give adequate subject coverage to the article?

Spiller cites three periodical articles on Joseph Dennie. One is in a nineteenthcentury periodical not indexed by a general periodical index. The other two are in periodicals indexed by general periodical indexes, but because the articles are primarily on other literary figures no reference is made to Dennie in the indexes. ${ }^{7}$ The remoteness of the Wordsworth article can be appreciated when one realizes that the Dictionary of American Biography in its article on Dennie does not mention Wordsworth.

\section{Statistical Results}

The statistical results of this study are outlined briefly in the table entitled "Distribution of Bibliographical Citations by Three Categories."

\section{Conclusions}

Despite its obvious limitations, certain tentative conclusions are warranted by this study:

1. The basic premise of this paper is confirmed beyond reasonable doubt. That is, subject bibliography has a great deal to offer the research worker in locating materials not otherwise available and in providing critical notes on the literature of a given field.

2. Many so-called standard bibliographies are out of date. The Encyclopaedia of the Social Sciences is between 15 and 20 years old. The situation in the field of the social sciences generally and history in particular is bad. To cite an example from another field, the Quarterly Cumulative Index Medicus is 18 months behind the current output of medical journals. In order to do an effective job in the Grosvenor Library Medical Department, we must do our own subject indexing. Conservatively estimated, this costs the library $\$ 1000$ per year, and this situation can undoubtedly be multiplied many times throughout the country. It seems to me that we have an important professional

7 Leary, Lewis. "Leigh Hunt in Philadelphia " Pennsylvania Magazine of History and Biography, $\ddot{70}$ : 270-280, I946; and Leary, Lewis. "Wordsworth in 39 I-393, I 943 .

Distribution of Bibliographical Citations by Three Categories*

\begin{tabular}{|c|c|c|c|c|c|c|c|c|c|c|c|}
\hline \multirow{2}{*}{$\begin{array}{l}\text { Source } \\
\begin{array}{l}\text { Encyclopaedia of } \\
\text { the Social Sci- } \\
\text { ences }\end{array}\end{array}$} & \multirow{2}{*}{$\begin{array}{c}\begin{array}{c}\text { No. of } \\
\text { Bibliog- } \\
\text { raphies } \\
\text { Analyzed }\end{array} \\
6\end{array}$} & \multirow{2}{*}{$\begin{array}{c}\text { No. of } \\
\text { Verifiable } \\
\text { Books } \\
\\
\mathrm{I}\end{array}$} & \multicolumn{3}{|c|}{$\begin{array}{l}\text { Distribution } \\
\text { of Books by } \\
\text { Categories } \\
\text { A B C }\end{array}$} & \multirow{2}{*}{$\begin{array}{c}\text { Per Cent } \\
\text { of Total } \\
\text { Books in } \\
\text { Categories } \\
\text { B and C } \\
\\
36\end{array}$} & \multirow{2}{*}{$\begin{array}{c}\text { No. of } \\
\text { Verifiable } \\
\text { Periodical } \\
\text { Articles } \\
\\
4\end{array}$} & \multicolumn{3}{|c|}{$\begin{array}{l}\text { Distribu- } \\
\text { tion of } \\
\text { Periodical } \\
\text { Articles } \\
\text { By Cate- } \\
\text { gories } \\
\text { A B C }\end{array}$} & \multirow{2}{*}{$\begin{array}{c}\text { Per Cent } \\
\text { of Total } \\
\text { Articles in } \\
\text { Categories } \\
\text { B and C } \\
\\
25\end{array}$} \\
\hline & & & 52 & 24 & 5 & & & 3 & o & I & \\
\hline Spiller & 9 & 87 & 45 & $2 I$ & $2 I$ & 48 & 46 & $3^{8}$ & 0 & 8 & 17 \\
\hline $\begin{array}{l}\text { Ebisch and } \\
\text { Schücking }\end{array}$ & I & 20 & 4 & 8 & 8 & 80 & I I & 6 & I & 4 & 45 \\
\hline
\end{tabular}

* For Explanation, see text. 
responsibility to secure the publication of new subject bibliographies and to assure the adequacy and timeliness of established subject bibliographies.

3. There is no substitute for good subject bibliography. It appears conservative to state that from 8 to 20 per cent of the material on a given subject can be found through good subject bibliography, if available, which cannot be found through the subject catalog and general periodical indexes. In certain subjects, an additional 15 to 60 per cent of the material may be found through subject bibliography but not through the other two more general bibliographical tools.

4. Good subject bibliography covering all fields of knowledge could replace the subject catalog. This is not a new idea, but I would like to add a note of caution in regard to it, particularly for the benefit of catalogers who become dejected when they read statements of this kind and immediately want to be transferred to a public service department. It will be years before we overcome the problems obstructing the production of inclusive and adequate subject bibliography.

5. Other things being equal, the more specific the subject coverage of a bibliography the more useful it is. This is apparent in $A$ Shakespeare Bibliography which is divided into very narrow categories. A research worker bringing a problem to a bibliography of this type is much more likely to find assistance than in a bibliography divided into general subdivisions. However, there is a significant corollary to this conclusion. As bibliography becomes more and more specific, the effort required to create it and the magnitude of the final bibliography become greater and greater. In other words, if a bibliography on Shakespeare is divided into six subheadings, no book will be cited more than six times in the bibliography; but if it is divided into roo subheadings, it is quite possible for a general book to be cited 40 or 50 times. Those people who are planning bibliography at the national and international level must not consider the problems confronting them insuperable. If we add these additional quantitative and qualitative elements, we do so at the expense of becoming unrealistic. On the other hand, there is little point of producing inclusive national or international bibliography unless it is of such nature as to be useful in the ways outlined in this paper.

6. No cataloger or periodical indexer who must cover a general field or fields can compete with the scholar who is producing subject bibliography. First, the scholar has the advantage in knowledge of his area of interest. Second, and more important, the subject bibliographer is working on entirely different principles from the subject cataloger and the periodical indexer. The bibliographer is interested in a limited field. He reads widely in a general field and in collateral fields; selects a part of a book which, to the subject cataloger, seems unworthy of emphasis; analyzes minute parts of periodical articles in the same way; and brings all of these materials together into subject bibliography giving it tremendous statistical advantages.

The cataloger works on obviously different principles. For example, Vannevar Bush's Modern Arms and Free Man is an outstanding book of the year, an outstanding book on the subject, and written by perhaps the greatest living authority in the field. The subject catalog lists this book under two subjects, WAR and MUNITIONS, despite the fact that the following subjects are discussed at length: RELIGION AND SCIENCE; COMMUNISM; DEMOCRACY ; TOTALITARIANISM ; WORLD WAR, I939-46-GER(Continued on page 227) 
they are today used far more than is admitted. But subject cataloging, the most intellectually demanding of present-day cataloging techniques, will come into its own.

One of the most fertile fields for the new tools is the control of materials which have already been indexed and abstracted, rather than directly of subject content. For example, "it would take the Rapid Selector only about 15 minutes to review all the entries that have appeared in the last 30 years in Chemical Abstracts." ${ }^{16}$ Hence indexes will continue to expand. And hence subject cataloging, in the sense of analysis of information, will require greater skill and higher standards of subject knowledge. Librarians who can qualify as subject special-

16 Ibid., p. I 19. ists will rise in esteem in the eyes of both their own and other professions.

It should be noted that it has been assumed that libraries and librarians will take the initiative in guiding the new bibliographic tools. But it is equally possible that just as indexes and bibliographies were given over to outside agencies, so the new devices will be grasped most eagerly by those who first realize their potentialities. If this comes to pass, if libraries do not seize the opportunity afforded by the new tools, it is all too probable that their research collections will be left to wither into innocuous desuetude while other agencies take over their research functions. Machines do not change human nature; but automotive transportation has certainly disposed of the horse and buggy.

\title{
Subject Bibliography Versus Subject Catalog
}

\author{
(Continued from page 2I4)
}

MANY; EDUCATION ; EVOLUTION; PHILOSOPHY; SCIENCESTUDY AND TEACHING; MEDICINE-STUDY AND TEACHING; and U.S. DEPARTMENT OF DEFENSE.

7. The time has passed when we need to debate the merits of good subject bibliography. The library profession wishes to assume some leadership in the production of subject bibliography. However, we do not have an adequate number of capable people in our profession to provide the leadership let alone the army of trained scholars necessary to do the spade work. Perhaps the latter is not a function of our profession, but if we are to assert leadership we must either develop capable bibliographers in adequate numbers within our profession or import them into librarianship from other fields.

\section{Rare Books in the University Library}

Rare Books in the University Library, published as Part II of the July 1949, issue of College and Research Libraries, and issued as a separate by A.C.R.L., received an impressive review in The (London) Times Literary Supplement for April 28, 1950. Copies of Rare Books in the University Library are still available at A.C.R.L. Headquarters, American Library Association, Chicago, Ill. 